\title{
Addressing the Human Rights of Older Persons and Vulnerable Populations
}

\author{
Susan Mapp ${ }^{1} \cdot$ Shirley Gatenio Gabel ${ }^{2}$
}

Published online: 22 November 2017

(C) Springer International Publishing AG, part of Springer Nature 2017

Human rights challenges continue unabated around the world. The articles in this issue span three continents and address topics in Chile, Ghana, South Africa, and the USA. Two of them focus specifically on human rights as they pertain to the elderly, while the others offer important information that can assist in work with this population. There is no Convention on the Rights of the Elderly, though there have long been calls for one. The Madrid International Plan of Action on Ageing developed by the United Nations (UN) in 2002 looked at issues in three priority areas: "older persons and development; advancing health and well-being into old age; and ensuring enabling and supportive environments" (p. 5). The importance of this topic is likely to grow as the United Nations (2011) states that the number of older persons is expected to reach 2 billion by 2050 when there will be more people over 60 years of age than under 18 years for the first time. The UN (2011) states that around the world, older persons are at risk of poverty, discrimination, and violence, and that they typically lack services and measures designed for them.

Noyoo examines the human rights situation of the elderly in South Africa and notes that although the country has a constitution and social welfare policy that are rights-based, this does not translate to effective policy for the elderly. Noyoo states that this young democracy has a high number of elderly living in poverty despite an old age pension and that rights-based policies are insufficient in themselves, supporting the findings of the $2011 \mathrm{UN}$ report. Relating to the supportive environment discussed in the Madrid Plan, Cox and Mainiero examined an environment in which many elderly live-a

Susan Mapp

mapps@etown.edu

1 Elizabethtown College, Elizabethtown, PA, USA

2 Fordham University, Bronx, NY, USA nursing home - and factors that can affect employee turnover, thus leading to a lower quality of life for the residents. They found that experience in such an environment increases reported respect towards residents and each other, which contributes to improved living and work environments.

Rice, Felizzi, and Hagelgans examine issues related to disasters in Chile. Utilizing a rights-based framework, they examined the community's response to a wildfire in Valparaiso, Chile, and found a strong sense of informal support and community, in the face of a lack of formal support from the government. They note that these informal support systems can be more effective than formal ones that may neglect marginalized communities.

Mfoafo-M'Carthy and Sossou discuss the situation faced by those with mental illness in Ghana. Similar to the elderly, those with mental illness also often cope with poverty, social exclusion, and stigmatization. These authors call for a more rights-based approach to assisting these individuals to lead fulfilling lives.

As we see human rights violations in populations around the world, such as increasing numbers of refugees, attacks on journalists, and impacts of climate change, it is also important to recognize the human rights violations that occur on a daily basis in all countries, such as those that affect the elderly and other vulnerable populations, and work to address them. The knowledge contained in these articles will assist us in doing so.

\section{References}

United Nations (2002). The Madrid international plan of action on ageing and the political declaration. Retrieved from http://www.un.org/esa/ socdev/documents/ageing/MIPAA/political-declaration-en.pdf.

United Nations (2011). Follow-up to the second world assembly on ageing. Report of the Secretary-General. Retrieved from https:// documents-dds-ny.un.org/doc/UNDOC/GEN/N11/428/83/PDF/ N1142883.pdf?OpenElement. 